\title{
Method for Sizing of a PV System for Family Home Using Economic Indicators
}

\author{
Zvonimir Šimić ${ }^{1}$, Danijel Topić ${ }^{1} \mathbb{1}$, Ilija Crnogorac ${ }^{2}$ and Goran Knežević ${ }^{1, *}$ \\ 1 Faculty of Electrical Engineering, Computer Science and Information Technology, Josip Juraj Strossmayer \\ University of Osijek, 31000 Osijek, Croatia; zvonimir.simic@ferit.hr (Z.Š.); danijel.topic@ferit.hr (D.T.) \\ 2 Croatian Transmission System Operator, 31000 Osijek, Croatia; ilija.crnogorac@hops.hr \\ * Correspondence: goran.knezevic@ferit.hr
}

check for updates

Citation: Šimić, Z.; Topić, D.;

Crnogorac, I.; Knežević, G. Method for Sizing of a PV System for Family Home Using Economic Indicators. Energies 2021, 14, 4529. https:// doi.org/10.3390/en14154529

Academic Editors: Alon Kuperman and Surender Reddy Salkuti

Received: 14 June 2021

Accepted: 23 July 2021

Published: 27 July 2021

Publisher's Note: MDPI stays neutral with regard to jurisdictional claims in published maps and institutional affiliations.

Copyright: (C) 2021 by the authors. Licensee MDPI, Basel, Switzerland. This article is an open access article distributed under the terms and conditions of the Creative Commons Attribution (CC BY) license (https:// creativecommons.org/licenses/by/ $4.0 /)$.

\begin{abstract}
This paper presents a method for finding an optimal photovoltaic (PV) system according to Croatian legislation. The PV sizing model, in which a decision on investment is made according to economic indicators, is made using MATLAB Software. Based on the input data, the monthly PV system production is calculated, and electricity price formed. According to the PV system production and electricity price, economic indicators are calculated and obtained as output data. The model input data are solar irradiation, load diagram, PV system costs and market price of electricity while the model output data are PV system production, savings, profit, incomes, Net Present Value (NPV) and Levelized Cost of Electricity (LCOE). The obtained economic indicators are presented graphically and used for decision making on an optimal PV system size. The presented model is applied and presented in a case study.
\end{abstract}

Keywords: photovoltaic; sizing; electricity price; economic indicators; NPV; LCOE

\section{Introduction}

Photovoltaic (PV) systems are currently one of the most used renewable energy sources (RES). There are on-grid and off-grid as well as small-scale and large-scale PV systems. Before the installation of a PV system, a sizing procedure is required. There are different methods for sizing of a PV system confirmed with many papers in the last two decades and especially in the last ten years.

The research on optimal design of a PV power system can already be found in the papers published in the first half of the last century 90s [1,2]. In [1], a detailed PV system design method including the sizing of the system components and calculating the system performances is established by analyzing the existing PV systems and interviewing expert PV engineers. In [2], in addition to minimizing the system life-cycle costs (purchase, maintenance and operations costs), the authors also take the inconvenience costs of unsupplied end uses into account.

Sizing of the PV system components for the off-grid operation is investigated in [3], where the designed system must meet the following objectives-evaluation of a local sun irradiation values and spectral content, a self-contained critical PV system that can power at least ten $10 \mathrm{~mA}$ LEDs; proper electric protection of all components; storage of unconsumed DC energy in batteries and maybe sell inverted AC energy back to the power grid. Another PV system optimization for a specified location using the time series data is presented in [4]. Experimental PV, storage and generator technologies are tested in this paper to meet the energy needs for a specified location. A microgrid model is developed according to the energy requirements and the insolation data. With the use of the hourly time-series data for exploring the cost and performance trade-space of the PV battery generation system, the cost optimization is performed. Authors highlight the flexibility cost, the impact of the optimum size of the system components on duration and the fully burdened cost of fuel. A cost comparison of two PV technologies used for the off-grid PV system by implementing a 
life-cycle costing (LCC) analysis technique is presented in [5]. Comparison is done between amorphous silicon (a-Si) and cadmium telluride (CdTe). The financial analysis of installing an off-grid PV system on a family house for four people is performed with using of a RETScreen simulation tool.

A simulation method for finding a size and cost effectiveness of a PV system for buildings are presented in [6,7] where objectives are based on different self-consumption aspects like minimizing the trade of energy with the grid, improving the grid stability or maximizing the system profitability. In [8], the authors investigate the sizing of a PV-system for a household considering the feed-in tariffs that are lower than the purchase tariffs. The calculations are done for a whole year period according to the solar irradiation data and the household energy consumption. The possibility of using an extra short-term energy storage system has also been researched in this work.

A hybrid approach which combines the analytical sizing equations with the long-term performance is presented in $[9,10]$. In [9], an optimal design of an off-grid photovoltaic (PV)-battery system is proposed while in [10], a simulation algorithm to estimate the total energy produced from a grid tied PV system for any selected location and for defined capacity is developed.

A method used to develop a regression model for finding a size of a stand-alone photovoltaic (SAPV) system, which predicts the operational requirements of an SAPV system according to selected location and the load conditions is presented in [11]. The application of this method is presented through the development of a couple of regression models for a specified case of sun irradiation, load and efficiency, which are the main inputs to this model. The proposed model is built on simulation of the long-term performance of an SAPV system.

In [12], the authors propose a methodology for modeling, sizing and cost analyzing of a PV system with batteries based on the multi-agent adaptive fuzzy neuronet. The main purpose of this study is finding the optimal system configuration and the sizing coefficient of a PV system based on the multi-agent adaptive fuzzy neuronet. In [13], the authors proposed a sizing methodology built on the observed extremes of solar radiation. An extreme value theory (EVT) based sizing methodology includes climate cycle recognition, sizing formulas construction and calculation of power loss probability.

A practical program for optimal sizing of a standalone PV system is presented in $[14,15]$. The authors in [14] present a method that is mainly numerically based and deals with the hourly solar irradiation data, load consumption and the outside temperature. To use the presented methodology for a PV system sizing, the methodology is supported by a graphical user interface (GUI). In [15], the authors focus is on the development of an open source tool for PV systems sizing, that is simple for the users, with an objective of facilitating the sizing and making solar energy more available, especially in the developing countries.

A meta-heuristic algorithm for sizing a PV system is used in [16-19]. According to [16], the results show that PV sizing algorithm based on dolphin echolocation algorithm is much better than PV sizing algorithms which use selected computational intelligence, i.e., evolutionary programming, firefly algorithm and cuckoo search. Algorithms are compared according to the lowest elapsed time and the highest NPV. In [17], to use the maximum output power of the PV system, the maximum power point tracking (MPPT) control algorithm based on particle swarm optimization (PSO) is presented. A methodology for sizing the PV modules based on the modified particle swarm optimization (MPSO) used to reduce energy losses and to improve voltage profiles is presented in [18]. The presented method is tested on the IEEE 13-bus test system and validated on a real micro grid of the Federal University of Paraiba (UFPB). According to the results, the presented methodology can provide sizing of PV modules distributed in a micro grid, improve the voltage profile and reduce energy losses. A comparison of the swarm optimization methods for MPPT in partially shaded PV systems is shown in [19]. Different methods are reviewed. The authors 
highlight that the particle swarm optimization (PSO) is the fastest and the artificial bee colony $(\mathrm{ABC})$ is the most accurate.

The authors in [20] argue that the meta-heuristic algorithms, introduced in the past, depend on the algorithm-specific parameters for reaching an optimal solution. Consequently, they propose a hybrid algorithm which is a combination of Jaya and a teaching-learningbased optimization (TLBO). This new proposed algorithm is called JLBO algorithm, and it is used for finding the optimal size of a PV-wind-battery hybrid system to cover consumption at the minimal total annual cost (TAC). According to the output results achieved from JLBO algorithm that are set against the original Jaya, TLBO and genetic algorithms, can be concluded that the JLBO algorithm shows better performance in related to TAC.

The idea of photovoltaic power sharing in power shared building communities for performance improvements is investigated in [21] where the authors propose a hierarchical design approach of distributed batteries in photovoltaic power shared building communities. The main purpose of the proposed approach is reducing the battery capacity and minimizing the energy losses in the sharing process. The proposed design approach first considers all distributed batteries as a virtually "shared" battery and finds its optimal capacity using a genetic algorithm (GA). The optimal capacity is then used as a restriction and the proposed approach optimizes the capacities of the distributed batteries for minimizing the energy losses using non-linear programming.

The PV system design, as a part of a comprehensive financial and renewable multiobjective optimization (FARMOO) algorithm for dairy farms, is presented in [22]. The FARMOO algorithm finds the optimal combination of equipment for dairy farms and management practices according to a trade-off parameter, which indicates the relative significance of maximizing farm net profit and farm renewable contribution.

In [23], the authors presented a mathematical model for finding an optimal configuration of the PV system for the defined installation area providing a maximal lifetime profit considering the inter-row shading on the PV module output power impact by introducing a shading factor. According to the case study results, there is a significant impact of the inter-row module partial shading on finding an optimal configuration of the PV system using the given PV module. Appropriate time shifting of the load has a significant impact on PV array sizing. In [24], the authors investigate the PV array sizing in a DC nano-grid for remote households after alteration in consumption time. Such alteration of consumption time decreases the storage system cost.

Recently, there has been a strong growth in the development of PV technologies and materials. The authors of [25] analyzed the progress related to the development of new PV technologies based on single crystalline, multi crystalline and polycrystalline materials. They compared the efficiency of different PV cell types considering factors that affect a PV cell power output. The authors of [26] analyzed perovskite solar cell technology ultrathin films.

This paper contributes with a method for finding an optimal size of a PV system, according to Croatian legislation, in which a decision is made according to economic indicators. The Croatian "Law of the renewable energy sources and the highly efficient cogeneration" defines a consumer with his own production. The prescribed methodology for forming a price of electricity produced from a PV system, which depends on the relationship between received and delivered electricity, is used. The proposed method is used for the calculation of PV system production on an hourly basis, incomes on a monthly and annual basis and NPV for the PV system during the lifetime period considering a degradation rate of PV modules.

This paper is divided into four chapters. In Section 1, an introduction and a literature overview are given. In Section 2, a mathematical model for PV system sizing is described. The model is applied on a family home case study in Section 3. Discussion and conclusions are given in Section 4. 


\section{Description of the Proposed Method}

For the PV system sizing, it is essential to determine the electricity consumption so the system can cover consumption at any time. The best way to determine consumption is by measuring the real consumption and recording a load diagram during a long period. If measurements are not possible or not feasible, consumption can be estimated based on a list of all electrical devices, devices working time and electric bills for the previous period. It is also required to estimate the PV system production and ensure that enough energy for covering consumption will be produced.

The presented model's task is to do detailed economic analyses and determine output indicators that will justify the selected PV system. The flowchart diagram of the presented PV sizing method is illustrated in Figure 1.

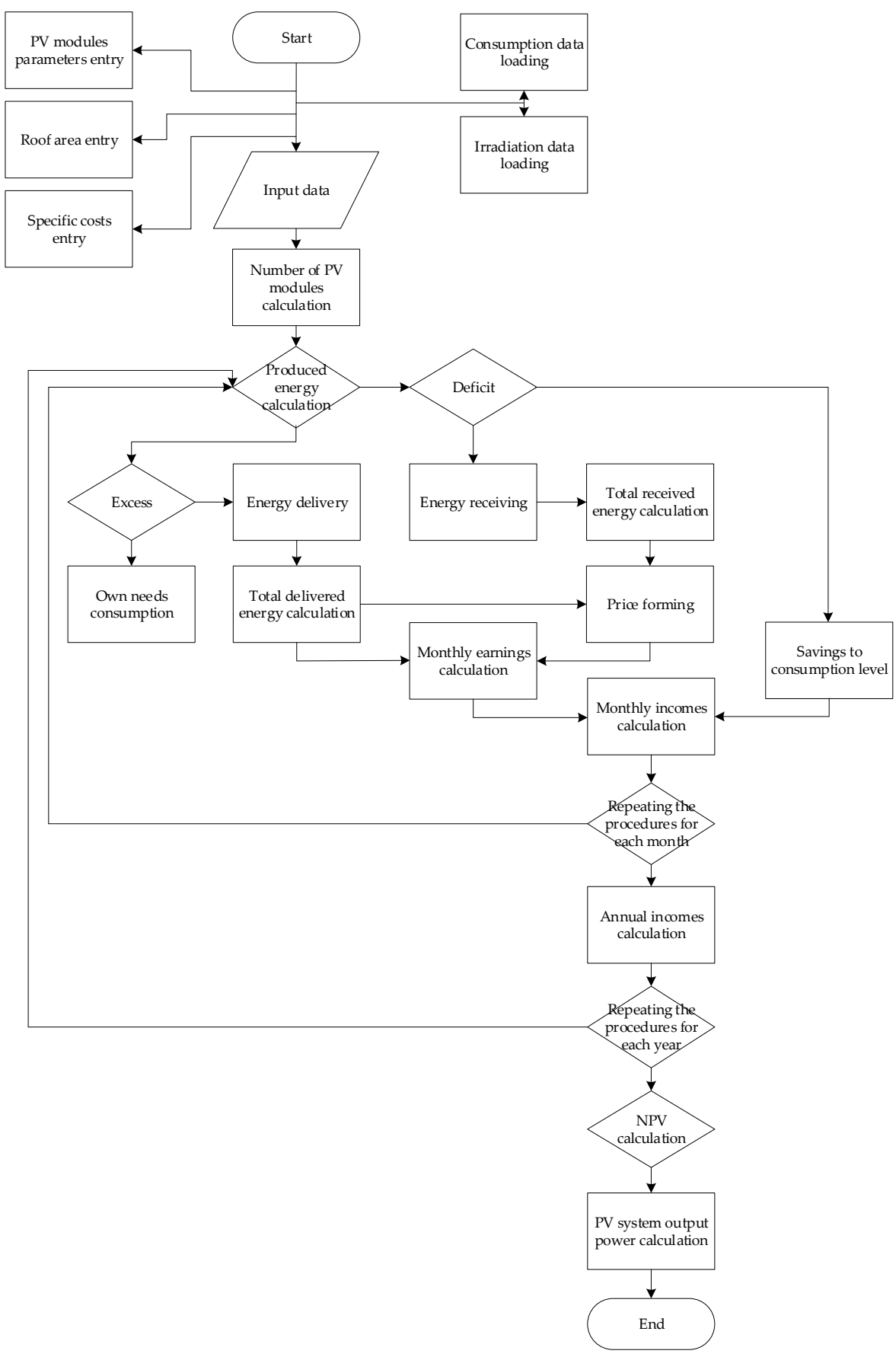

Figure 1. Flowchart diagram of the proposed method. 
First step in the presented method is the input data loading. Required input data are: the PV modules parameters, the family house roof area, the PV system specific costs, consumption and the irradiation data. When all the required input data is entered, next step is the calculation of the maximum number of the PV modules which is limited with the roof area. Energy produced in PV system in one hour can be calculated as a product of solar irradiation, area of single PV module, efficiency of PV module and the number of PV modules. Area of the single PV module and efficiency are the PV module parameters implemented in model as the input data.

The algorithm calculates the energy produced from the PV system up to the maximum number of the PV modules hourly during the one month and compares the produced energy with consumption. If the amount of produced energy is higher than the amount of load, there is an energy excess. The algorithm calculates the energy consumption for own needs and the energy delivered to the grid. If the amount of produced energy is lower than the amount of load, there is an energy deficit. The algorithm calculates savings to the consumption level and the energy received from the grid. According to the amounts of received and delivered energy, the electricity price is formed, and the monthly earnings are calculated. The monthly incomes are calculated by summing up the monthly earnings and savings. After that, the sizing procedure is repeated for each month during one year and the annual incomes are calculated. After that, the sizing procedure is repeated for each year during the PV system lifetime period and the total lifetime incomes are calculated. According to the total incomes during the whole lifetime period, the NPV is calculated. According to the NPV, the output power of the PV system is calculated and decision on the most profitable size of the PV system is made.

\subsection{Input Model Data}

For the presented PV sizing model, requested input data are solar irradiation, which can be used to estimate the PV production, load diagram estimating the annual cost of electricity, PV system total costs and electricity market price.

\subsubsection{Solar Irradiance}

PV production can be estimated according to solar irradiance data received from a photovoltaic geographical information system (PV GIS) [27]. First, it is required to select a location, then select slope and azimuth. Slope is the angle between the PV module and the horizontal plane. In the case of a house with a sloping roof, the angle is predetermined and in the case of a flat roof or flat ground, it is required to find an optimal angle or implement a tracking system for better utilization of solar radiation. Azimuth or orientation is the angle of the PV module in relation to the south. Hourly, monthly or annually solar irradiation data can be received from PV GIS. Hourly solar irradiation gives the most precise data for produced energy estimation. PV system output power can be estimated according to Equation (1).

$$
P_{\mathrm{PV}}=A \cdot G \cdot n \cdot \eta
$$

where:

- $\quad P_{\mathrm{PV}}(\mathrm{W})-\mathrm{PV}$ system output power;

- $G\left(\mathrm{~W} / \mathrm{m}^{2}\right)$-solar irradiance;

- $\quad n$-number of PV modules;

- $A\left(\mathrm{~m}^{2}\right)$-area of module;

- $\quad \eta$-PV module efficiency.

\subsubsection{Load Diagram}

Load diagram is a very important factor for PV system sizing. Consumption data show when there is a high request for electricity. This paper uses a load diagram recorded through one week with the assumption that the load will not significantly change during a year. The load diagram is shown in Figure 2. According to the load diagram, the annual 
electricity cost can be calculated. Electricity price in Croatia, including fees and taxes, is $0.14 \mathrm{EUR} / \mathrm{kWh}$ in the high tariff and $0.072 \mathrm{EUR} / \mathrm{kWh}$ in the low tariff. Electricity cost is obtained by multiplying the high tariff price with consumption between 7 AM and 9 PM or $8 \mathrm{AM}$ and $10 \mathrm{PM}$, which depends on the winter and summer time calculation and by multiplying the low tariff price with consumption between 9 PM and 7 AM or 10 PM and $8 \mathrm{AM}$, which also depends on the winter and summer time calculation.

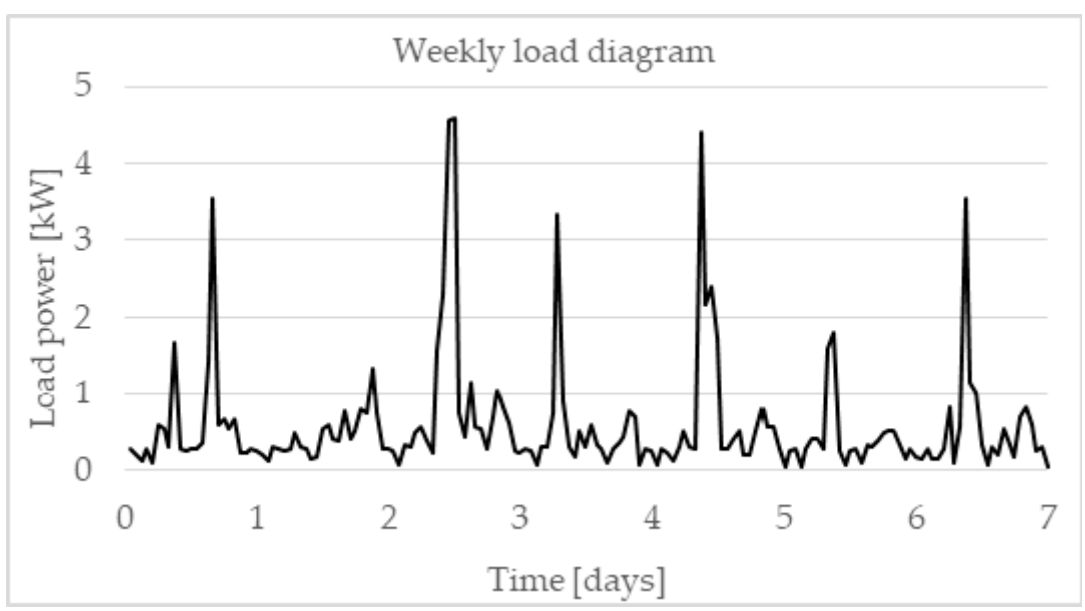

Figure 2. Load diagram.

\subsubsection{PV System Cost}

The total cost of the PV system consists of parts required for proper operation and functioning of the PV system. Specific prices of PV modules, assembly elements, cables, charging regulator, inverter, bidirectional electricity meter and batteries are shown in Table 1 [28].

Table 1. Specific prices of PV system parts.

\begin{tabular}{cc}
\hline Element & Cost \\
\hline PV modules & $733.33 \mathrm{EUR} / \mathrm{kW}$ \\
Assembly elements & $33.33 \mathrm{EUR} / \mathrm{kW}$ \\
Cables & $4.67 \mathrm{EUR} / \mathrm{kW}$ \\
Charging regulator/Inverter & $233.33 \mathrm{EUR} / \mathrm{kW}$ \\
Bidirectional electricity meter & $438.5 \mathrm{EUR} / \mathrm{kW}$ \\
Batteries & $146.67 \mathrm{EUR} / \mathrm{kWh}$ \\
\hline
\end{tabular}

In addition to the listed costs, investment costs include costs of technical documentation, electrical installation works and commissioning, which are separate items in the main project cost estimates.

\subsubsection{Market Electricity Price}

When sizing a PV power plant, it is required to select a combination of production and consumption at the highest electricity price. According to the Law of renewable energy sources and highly efficient cogeneration [29] in Croatia, the price of electricity produced from the PV system can be defined according to a relation between the received and delivered electricity as in Table 2.

Table 2. Electricity price forming.

\begin{tabular}{cc}
\hline$E_{\text {received }}>E_{\text {delivered }}$ & $E_{\text {received }}<E_{\text {delivered }}$ \\
\hline$C_{\mathrm{i}}=0.9 \cdot \mathrm{PKCi}$ & $C_{\mathrm{i}}=0.9 \cdot \mathrm{PKCi} \cdot \frac{E_{\text {received }}}{E_{\text {delivered }}}$ \\
\hline
\end{tabular}


Where:

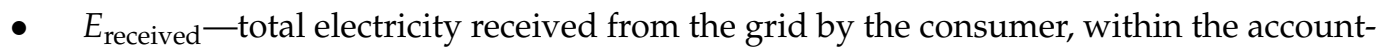
ing period, expressed in $\mathrm{kWh}$;

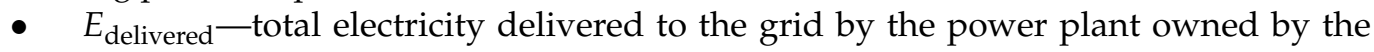
consumer, within the accounting period, expressed in $\mathrm{kWh}$;

- $\quad$ PKCi-average unit price of electricity, which a consumer pays to the energy supplier for received electrical energy, without grid-related fees and other fees and taxes, within the accounting period, expressed in EUR per kWh.

For better price prediction, it is required to estimate the produced energy, energy delivered to the grid and received energy. It is also required to predict electricity consumption. Savings can be defined as a share of energy, which a consumer with his own production does not buy but produces in his own power plant. Profit can be defined as a fee for electricity, which a consumer with his own production gets for the energy delivered to the grid. By summing profit and savings, incomes of the PV system are obtained.

Additional conditions for PV system sizing, used to redeem energy surplus, are defined pursuant to the Law of renewable energy sources and highly efficient cogeneration [29], as following:

- $\quad$ owners of PV systems have a status of a privileged electrical energy producer;

- $\quad$ owners of PV systems have the right to a permanent connection to the grid;

- connected power of a consumer with his own production does not exceed the power of a consumer without his own production.

\subsection{Output Model Data}

For the presented PV sizing model, output data are PV system electricity production and the following economic indicators-savings, profit, incomes, net present value and levelized electricity cost.

\subsubsection{PV System Electricity Production}

Hourly electricity production of the PV system for a different number of PV modules can be calculated according to Equation (2).

$$
P_{\mathrm{PV}, \mathrm{i}}=j \cdot \mathrm{G}_{i} \cdot A \cdot \eta \cdot s_{\mathrm{g}}
$$

where:

- $\quad P_{\mathrm{PV}, \mathrm{i}}$-hourly PV system electricity production;

- $\quad j$-number of PV modules;

- $\mathrm{G}_{i}\left(\mathrm{~W} / \mathrm{m}^{2}\right)$-hourly solar irradiance;

- $A\left(\mathrm{~m}^{2}\right)$-area of module;

- $\quad \eta$-PV module efficiency;

- $s_{\mathrm{g}}$-degradation rate impact.

The impact of a degradation rate can be calculated according to Equation (3).

$$
s_{\mathrm{g}}=1-(g-1) \cdot \frac{d_{\mathrm{r}}}{100}
$$

where:

- $\quad g$-number of years;

- $d_{\mathrm{r}}(\%)$-degradation rate.

The next step is to compare the PV system production with the load power and there are two possible cases. The first case is that the PV system production is higher than the load consumption according to Equation (4) and the second case is that the PV system production is lower than the load consumption according to Equation (5).

$$
P_{\mathrm{PV}, \mathrm{i}}>P_{\mathrm{LOAD}, \mathrm{i}}
$$




$$
P_{\mathrm{PV}, \mathrm{i}}<P_{\mathrm{LOAD}, \mathrm{i}}
$$

\subsubsection{Savings, Profit and Incomes}

If the PV system production is higher than the load consumption, there is an excess of energy which can be delivered to the grid. Delivered energy can be calculated monthly according to Equation (6). There are savings that can be calculated according to Equation (7) and profit that can be calculated according to Equation (8).

$$
E_{\text {delivered }}=\sum_{i=1}^{M} P_{\mathrm{PV}, \mathrm{i}}-P_{\mathrm{LOAD}, \mathrm{i}}
$$

where:

- $\quad P_{\mathrm{PV}, \mathrm{i}}-$ hourly PV system electricity production;

- $\quad P_{\mathrm{LOAD}, \mathrm{i}}$-hourly load electricity consumption;

- $\quad M$-total number of hours in the observed month;

- $\quad i-$ number of hours.

$$
\begin{gathered}
C_{\text {savings } 1}=\sum_{i=1}^{M} P_{L O A D, i} \cdot C_{i} \\
C_{\text {profit }}=\sum_{i=1}^{M}\left(P_{P V, i}-P_{L O A D, i}\right) \cdot C_{i}
\end{gathered}
$$

If the PV system production is lower than the load consumption, there is a deficit of energy, which needs to be received from the grid. Received energy can be calculated monthly according to Equation (9). There are savings that can be calculated according to Equation (10).

$$
\begin{gathered}
E_{\text {received }}=\sum_{i=1}^{M} P_{L O A D, i}-P_{P V, i} \\
C_{\text {savings } 2}=\sum_{i=1}^{M} P_{P V, i} \cdot C_{i}
\end{gathered}
$$

Total savings are equal to the sum of savings in the first case and savings in the second case according to Equation (11) and the total incomes are equal to the sum of profit and total savings according to Equation (12).

$$
\begin{gathered}
C_{\text {savings }}=C_{\text {savngs } 1}+C_{\text {savngs2 }} \\
C_{\text {incomes }}=C_{\text {profit }}+C_{\text {savings }}
\end{gathered}
$$

\subsubsection{Net Present Value}

Detailed economic analysis is required for the PV system selection. There are several different techniques for PV system investments and the most frequently used is the net present value (NPV). This approach can help with the financial part of a project, which determines if the project outcome will be positive or negative. The NPV integrates initial investment and expected incomes and costs with time and transforms it in the series of money flow adapted to time value of money and risk. The net present value can be calculated according to Equation (13) [30].

$$
N P V=-I+\sum_{g=0}^{G} \frac{C_{g}}{(1+r)^{\mathrm{n}}}
$$

where:

- I-initial investment; 
- C-net money flow;

- $r$-discount rate;

- $G$-lifetime of a PV power plant.

\subsubsection{Levelized Electricity Cost}

In order to estimate the justification and profitability of the PV system, in comparison to the other power plants, it is required to calculate the levelized cost of electricity (LCOE). The levelized cost of electricity can be defined as electrical energy production costs and can be calculated according to Equation (14) [31].

$$
L C O E=\frac{O C S \cdot C R F \cdot F O \& M C}{\frac{E_{0}}{N} \cdot \sum_{\mathrm{k}=1}^{\mathrm{N}}\left(1-\frac{d_{\mathrm{r}} \cdot(k-1)}{100}\right)}
$$

where:

- OCS-overnight capital cost;

- $\quad C R F$ - capital recovery factor;

- FOEMC - fixed operation and maintenance cost;

- $\quad E_{0}$-annually produced electrical energy;

- $d_{\mathrm{r}}$-degradation rate of the PV module;

- $\quad N$-number of years.

The capital recovery factor can be calculated according to Equation (15) [30].

$$
C R F=\frac{W A C C \cdot(W A C C+1)^{\mathrm{N}}}{(W A C C+1)^{\mathrm{N}}-1}+k_{\mathrm{ins}}
$$

where:

- WACC - weighted average cost of capital;

- $k$-annual insurance cost.

\section{Results}

This section presents the results of the case study in which the PV sizing algorithm is applied on family home PV system sizing. The first step is to select a PV module. When selecting a PV module, it is necessary to consider several things and one of the most important is a specific price. The most common modules available on the market are monocrystalline and polycrystalline silicon modules. BISOL BMO 250 module with characteristics listed in Table 3 is used in this case [32].

Table 3. Characteristics of PV module BISOL BMO 250.

\begin{tabular}{cc}
\hline Characteristic & Value \\
\hline Maximum power $\left(P_{\mathrm{MPP}}\right)$ & $250 \mathrm{~W}$ \\
Open circuit voltage $\left(U_{\mathrm{OC}}\right)$ & $37.9 \mathrm{~V}$ \\
Short circuit current $\left(I_{\mathrm{SC}}\right)$ & $8.6 \mathrm{~A}$ \\
Voltage at maximum power $\left(U_{\mathrm{MPP}}\right)$ & $30.5 \mathrm{~V}$ \\
Current at maximum power $\left(I_{\mathrm{MPP}}\right)$ & $8.2 \mathrm{~A}$ \\
Cell efficiency $\left(\eta_{\mathrm{C}}\right)$ & $17.4 \%$ \\
Module efficiency $\left(\eta_{\mathrm{M}}\right)$ & $15.3 \%$ \\
\hline
\end{tabular}

In addition to the price, it is necessary to pay attention to the warranty provided by the producer and take the degradation factor into account. Due to aging, over time, modules give less energy for the same solar irradiation. For BISOL BMO 250 the manufacturer guarantees module output power $80 \%$ of the nominal value after 25 years, which means that the degradation factor is 0.8. In addition to the electrical characteristics, thermal and mechanical characteristics are very important for PV modules. Thermal characteristics are very important to calculate the maximum and minimum values of the current and 
voltage that may occur and damage the inverter. Mechanical characteristics are dimensions, weight, number of cells, glass characteristics, allowed load, etc. Dimensions of PV module BISOL BMO 250 are 1649 by $991 \mathrm{~mm}$.

The second step is to check the maximum number of modules done in Matlab by dividing the area of the roof with the area of one module. Then the obtained value is fixed to the first lower whole number.

When the PV module technology is selected and the number of PV modules is obtained, irradiation data from PV GIS [27] can be received. In PV, GIS location is entered first. After that, a slope of $35^{\circ}$ and azimuth of $80^{\circ}$ for the selected location are entered. Hourly irradiation data is downloaded in an excel file and then imported in Matlab from the excel file.

\subsection{Energy Flow Calculations and Price Forming}

When the load and irradiation data are imported and module parameters entered, production for $n$ modules can be calculated. With calculated production and known load, energy flows can be calculated. If produced energy is higher than load energy, it means that there is an energy excess, which is delivered to the grid. This energy excess is equal to a difference between produced and consumed energy. The amount of energy delivered to the grid depends on the number of modules and grows linearly as shown in Figure 3.

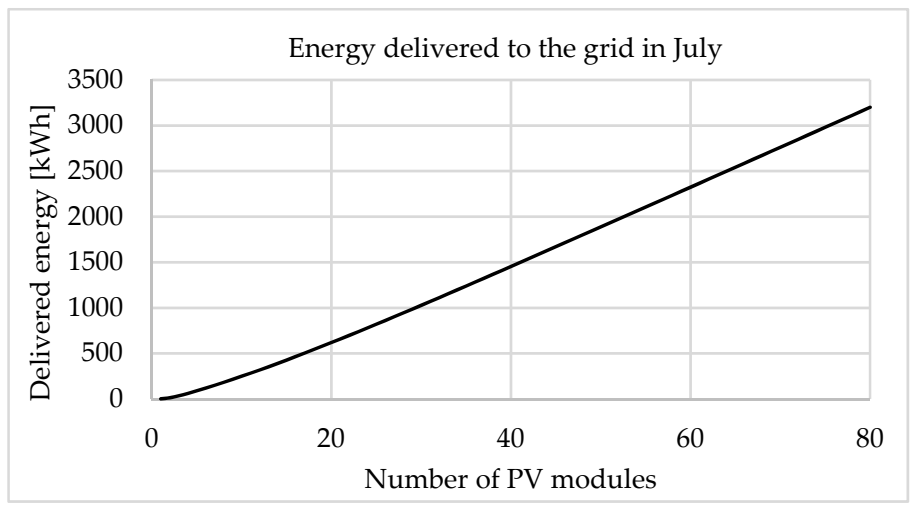

Figure 3. Amount of energy delivered to the grid related to the number of PV modules.

If produced energy is lower than required, there is a lack of energy, which needs to be received from the grid. As the installed power of the PV system increases, there is a lower need for energy from the grid. A price of electrical energy is formed according to Table 2, and it can be assumed that the price decreases with the increase of delivered energy. According to the Law of renewable energy sources and highly efficient cogeneration [29], the accounting period for consumers with their own production is one month, so it is necessary to calculate delivered and received energy every month for correct price forming and incomes determination. The price of electrical energy for consumers in Croatia is $0.045 \mathrm{EUR} / \mathrm{kWh}$ for the low tariff and $0.072 \mathrm{EUR} / \mathrm{kWh}$ for the high tariff, prices are expressed without fees and taxes. $P K C i$ is estimated at $0.058 \mathrm{EUR} / \mathrm{kWh}$. The impact of the number of PV modules on the electricity price is shown in Figure 4. The impact of the number of PV modules on the incomes is shown in Figure 5.

\subsection{Economic Indicators Calculations}

To make a final decision about PV system size selection, the next step is to calculate total annual incomes. For more precise income determination during the whole PV system lifetime, a degradation rate of a PV module is considered. A degradation rate does not have a large impact on incomes, which can be seen in Figure 6. 


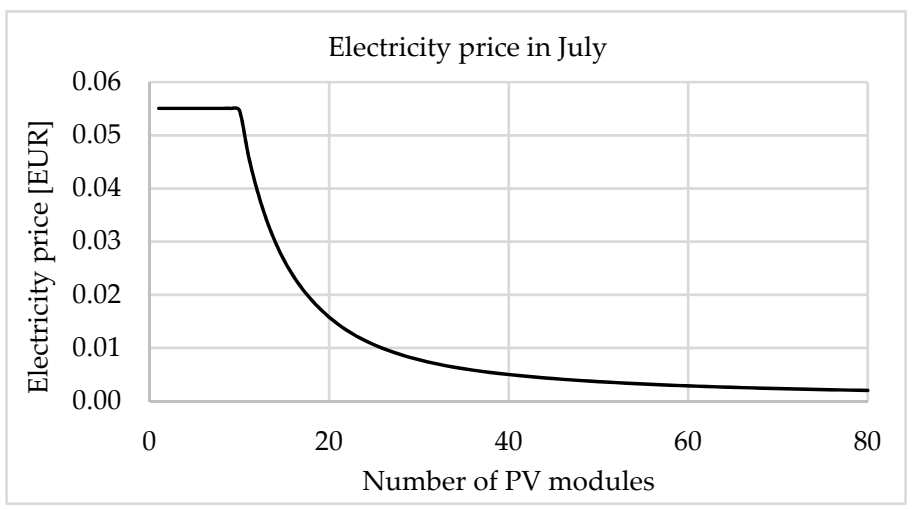

Figure 4. Electricity price related to the number of PV modules.

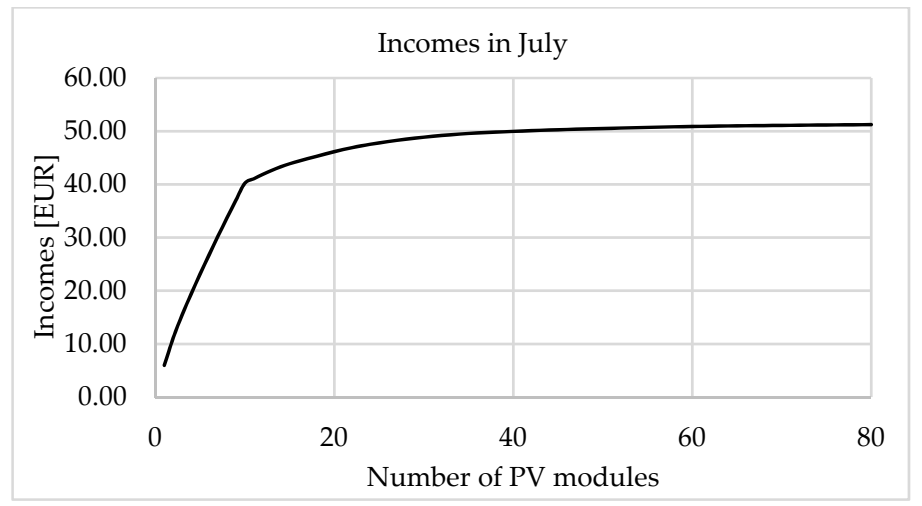

Figure 5. Incomes related to the number of PV modules.

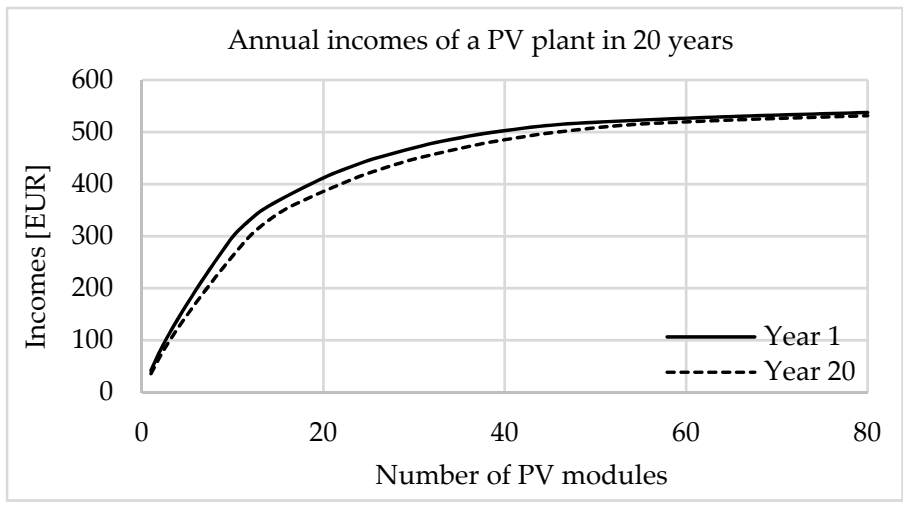

Figure 6. Annual incomes of a PV plant for the period of 20 years.

Incomes are linearly increasing up to a certain number of PV modules because received energy is greater than delivered and the price is not changing. As the number of PV modules increases, the amount of delivered energy is greater than received and the price decreases, incomes are growing slowly. As the number of PV modules further increases, the amount of delivered energy is much greater than received and the price is very low, incomes stop growing. It can be assumed that as the number of PV modules increases, production increases but it leads to the lower price of electricity.

\subsubsection{NPV Calculation}

The last step is to conduct an economic analysis using the NPV method. It is required to calculate costs for $n$ modules according to Equation (2). What is very important for NPV calculation is a discount rate. The most frequently used discount rates are $0,3,5$ 
and $10 \%$. To determine NPV, it is required to determine the net money flow matrix, which represents annual incomes of the PV system reduced by maintenance costs. Maintenance costs consider failures and replacing some parts of the PV system, which is usually $2 \%$ of the investment. Figure 7 illustrates that the greatest NPV is for 11 PV modules, but since 11 is an uneven number, 12 PV modules are used because of the second greatest NPV value.

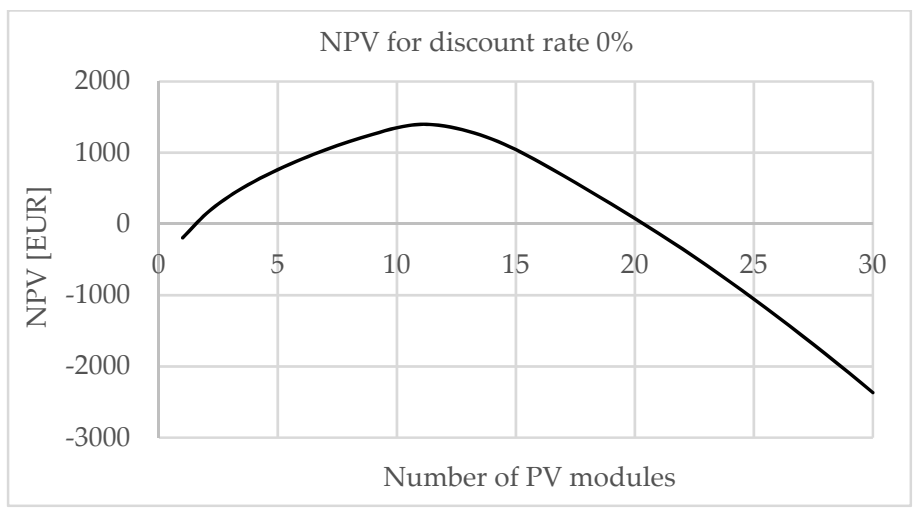

Figure 7. NPV for discount rate of $0 \%$.

To determine a return-on-investment time, the net money flow data for the PV system with 12 PV modules is presented in Figure 8, which demonstrates that a return-oninvestment time is less than 15 years.

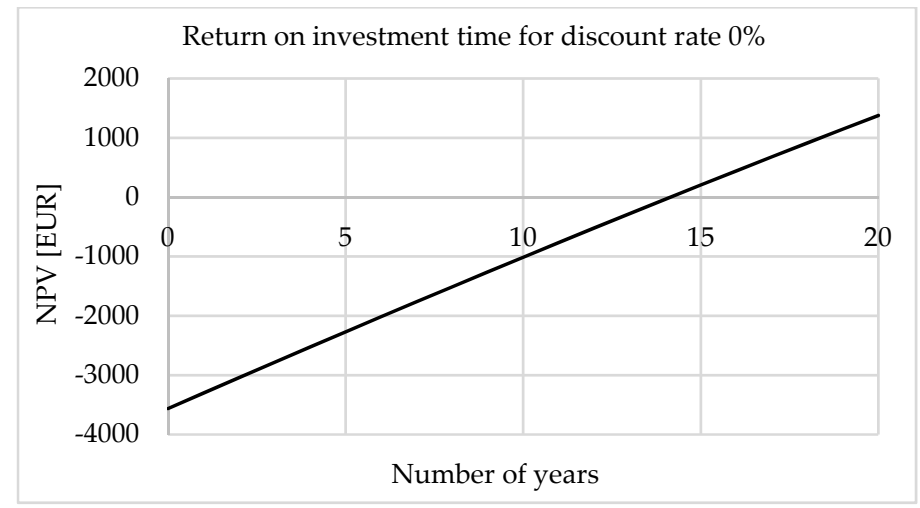

Figure 8. Return-on-investment for time discount rate of $0 \%$.

During the last years, the Croatian National Bank kept the discount rate at 3\%. NPV calculation for this discount rate is presented in Figure 9 illustrating that a PV system is cost effective between 4 and 13 PV modules with power between 1 and $3.25 \mathrm{~kW}$, i.e., the most effective decision is $10 \mathrm{PV}$ modules or power of $2.5 \mathrm{~kW}_{\mathrm{p}}$.

Figure 10 shows the return-on-investment time for the PV system with 10 PV modules. Return-on-investment time is 17 years for a discount rate of $3 \%$, which is most likely.

Profit is very low. Savings achieved with 2.5 and $3 \mathrm{~kW}_{\mathrm{p}}$ systems can be seen in Figure 11. Savings are $30 \%$ of the current electricity costs.

For the discount rates of 5 and 10\%, NPV is negative as demonstrated in Figures 12 and 13 which means that the system is not profitable.

\subsubsection{LCOE Calculation}

According to Equation (3), a code that calculates LCOE is made. The first step is to estimate one-year PV system electricity production and the second one is to estimate the whole lifetime considering a degradation rate. As investment and maintenance costs are calculated, it is required to determine a capital recovery factor according to Equation (4). 
With a weighted average cost of capital with 3,5 and $10 \%$, the following results, shown in Figure 14, are obtained.

For the low number of PV modules and less installed power, LCOE is higher than for the high number of PV modules. It is because there are fixed investment costs, which occur during PV plant construction. As the number of PV modules increase, investment costs are growing linearly but the production of electricity is also growing and LCOE is not changing significantly.

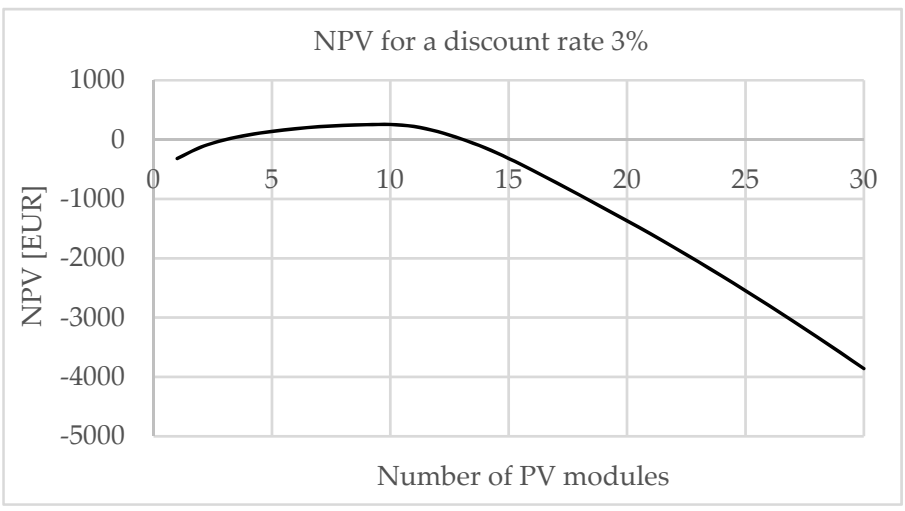

Figure 9. NPV for a discount rate of $3 \%$.

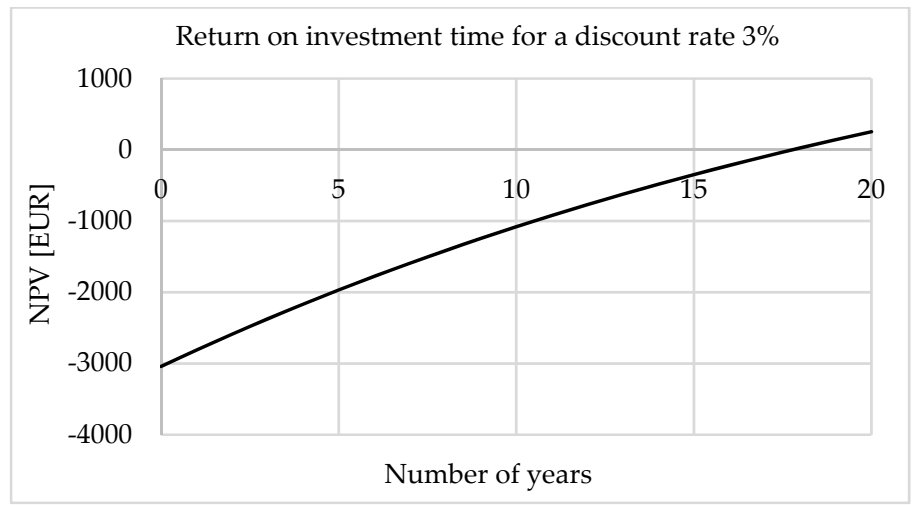

Figure 10. Return-on-investment time for a discount rate of 3\%.

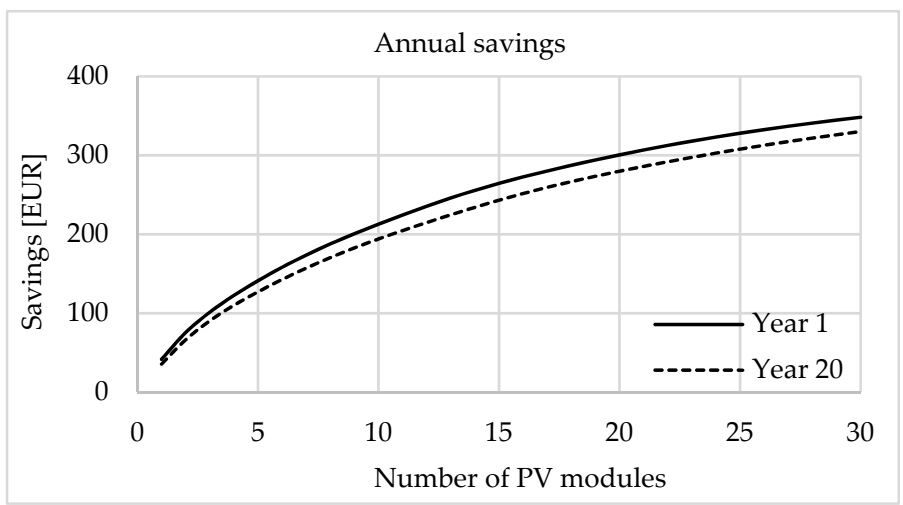

Figure 11. Annual savings for the period of 20 years. 


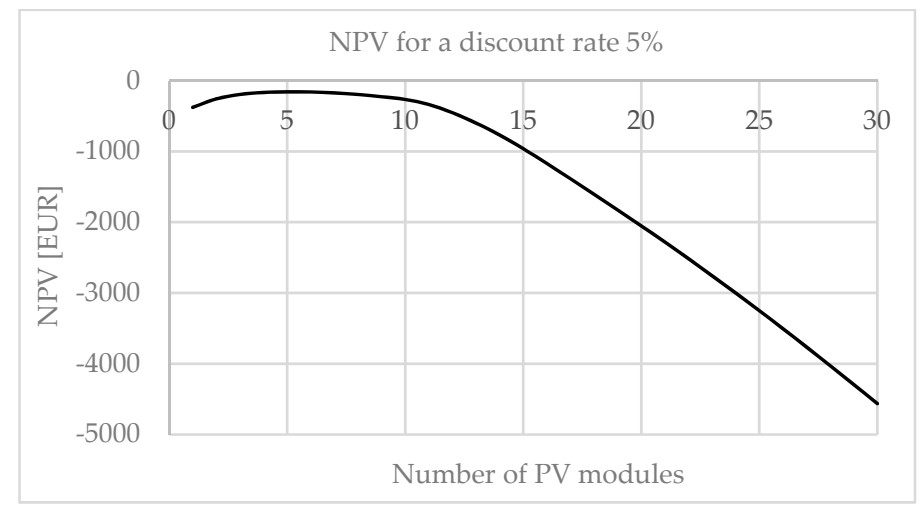

Figure 12. NPV for a discount rate of $5 \%$.

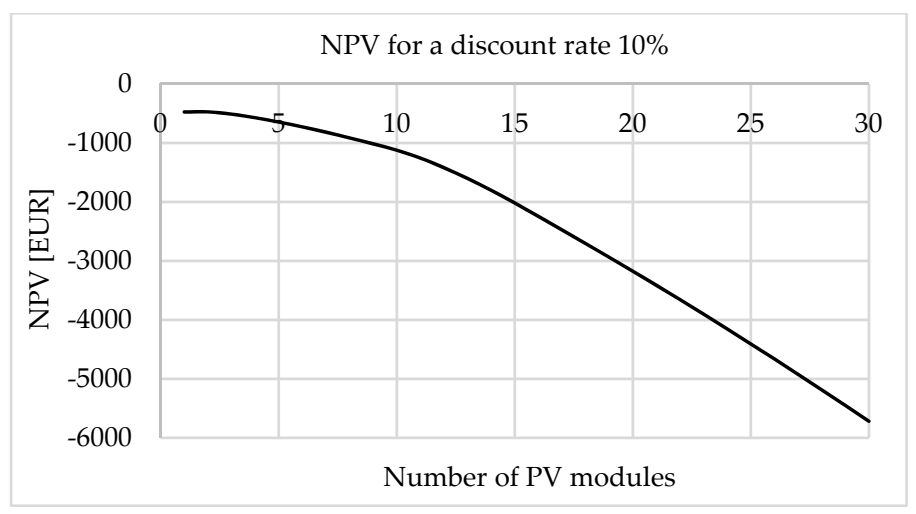

Figure 13. NPV for a discount rate of $10 \%$.

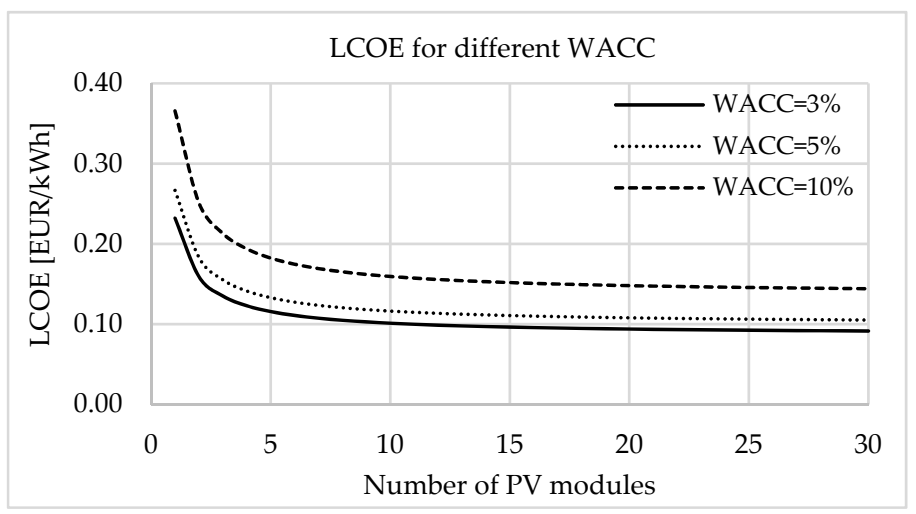

Figure 14. LCOE for different WACC.

\section{Discussion and Conclusions}

The presented method for PV system sizing, according to economic indicators, is applied to a family home case study. Specifics of the electricity pricing in Croatia is considered where the price of electricity produced from a PV system is defined according to relation between received and delivered electricity. Proposed method is used for the calculation of PV system production on an hourly basis, incomes on the monthly and annual basis and the NPV for the PV system during the lifetime period considering degradation rate of PV modules. The temperature impact on the PV module is not considered in this paper. Power flow calculation illustrates that the amount of energy delivered to the grid increases as the number of PV modules increases. The electricity price is constant up to $10 \mathrm{PV}$ modules $\left(2.5 \mathrm{~kW}_{\mathrm{p}}\right)$ and as the number of PV modules increases, electricity prices 
decrease. For the large number of PV modules, electricity prices are very low. Incomes of $\mathrm{PV}$ plants increase rapidly up to $10 \mathrm{PV}$ modules and for more than $40 \mathrm{PV}$ modules $\left(10 \mathrm{~kW}_{\mathrm{p}}\right)$, there is not a significant increase in incomes. NPV calculation is done for different discount rates $(0,3,5$ and $10 \%)$. For discount rates of 5 and $10 \%$, PV systems are not profitable because NPV does not achieve the positive value for any number of PV modules. For a discount rate of $0 \%$, NPV achieved the positive value between 2 and 20 PV modules and the highest value is for $11 \mathrm{PV}$ modules. Since 11 is an uneven number, for making a combination of parallel and serial PV string, the decision is to use $12 \mathrm{PV}$ modules. Returnon-investment time in this case is less than 15 years. For a discount rate of $3 \%$, NPV achieved the positive value between 4 and 13 PV modules and the highest value is for $10 \mathrm{PV}$ modules. Return-on-investment time in this case is 17 years. LCOE shows the electricity production costs, and in this paper, it shows the cost of electricity produced in the PV system for the family home related to different numbers of the PV modules. LCOE calculation, which is done for different values of WACC (3, 5 and $10 \%)$, shows that LCOE decreases as the number of PV modules increases; LCOE significantly decreases up to 10 PV modules and for more than 15 PV modules, it does not significantly decrease.

The method for PV system sizing can be applied to other European countries with legislatives different from Croatian. In this case, the method is applied on the same PV system for a family home located in Germany and Spain. There is less solar irradiation in Germany than in Croatia, which results in lower electricity production from the PV system. The electricity price in Germany is $0.30 \mathrm{EUR} / \mathrm{kWh}$ [33] and there is a fixed feed-in tariff of $0.1183 \mathrm{EUR} / \mathrm{kWh}$ for PV systems below $10 \mathrm{~kW}_{\mathrm{p}}$ according to [34]. There is more solar irradiation in Spain than in Croatia, which results in higher electricity production from the PV system. The electricity price in Spain is $0.23 \mathrm{EUR} / \mathrm{kWh}[33]$ and there is no feed-in tariff for PV systems below $100 \mathrm{~kW}_{\mathrm{p}}$ according to [34]. The results of the German and Spanish case studies are compared with the Croatian case study results. The comparison of NPV values between Croatia, Germany and Spain for different discount rates $(0,3,5$ and $10 \%$, respectively) is shown in Figure 15.
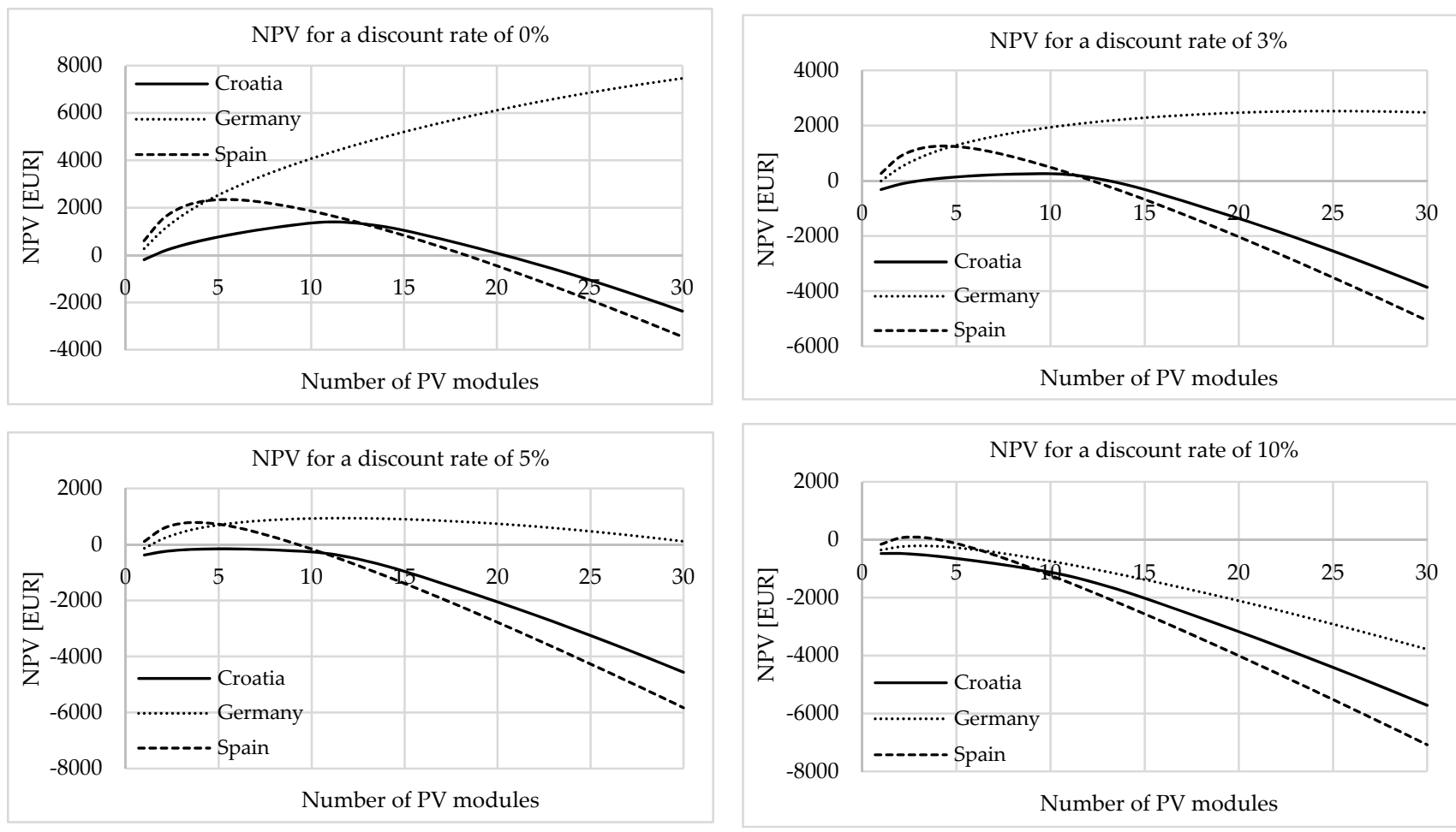

Figure 15. Comparison of NPV for the discount rates of $0,3,5$ and 10\% between Croatia, Germany and Spain. 
Diagrams in Figure 15 demonstrate that the observed PV system is very profitable in Germany although there is less solar irradiation and lower production of electricity from the PV system than in Croatia and Spain. The reasons for that are the higher electricity price in Germany, which results in the higher savings and fixed feed-in tariff, which results in higher earnings. The PV system in Spain is profitable for the low number of PV modules and not profitable for the high number of PV modules although there is more solar irradiation and more production of electricity from the PV system than in Croatia and Germany. The electricity price in Spain is lower than in Germany but the main reason for lower profitability at a higher number of PV modules is the absence of any compensation for the surplus of energy delivered to the grid. It means that investments in small PV systems in Spain are profitable only for covering one's own consumption.

According to diagrams in Figure 15, which show NPV values for different discount rates, the observed PV system in Spain is profitable up to $18 \mathrm{PV}$ modules $(4.5 \mathrm{~kW}$ ) for a discount rate of $0 \%$, up to $12 \mathrm{PV}\left(3 \mathrm{~kW}_{\mathrm{p}}\right)$ modules for a discount rate of $3 \%$, up to $9 \mathrm{PV}$ modules $\left(2.25 \mathrm{~kW}_{\mathrm{p}}\right)$ for a discount rate of $5 \%$ and from 2 to $4 \mathrm{PV}$ modules $\left(0.5\right.$ to $\left.1 \mathrm{~kW}_{\mathrm{p}}\right)$ for a discount rate of $10 \%$. Only the PV system in Spain is profitable for a discount rate of $10 \%$ and this is because of high solar irradiation. The observed PV system in Germany is very profitable for the discount rates of 0 and $3 \%$, profitable up to $30 \mathrm{PV}$ modules $\left(7.5 \mathrm{~kW}_{\mathrm{p}}\right)$ for a discount rate of $5 \%$ and not profitable for a discount rate of $10 \%$. For a discount rate of $5 \%$, the observed PV system is profitable in Germany and Spain and for a discount rate of $10 \%$, only in Spain up to 4 PV modules $\left(1 \mathrm{~kW}_{\mathrm{p}}\right)$.

A comparison of LCOE between Croatia, Germany and Spain for different WACC (3, 5 and $10 \%$ ) is shown in Figure 16. LCOE is the highest for the German case study because of the higher electricity price and fixed feed-in tariff while LCOE is the lowest for the Spanish case study because there is no feed-in tariff. LCOE for the Spanish case study is slightly lower than for the Croatian case study. The difference between Spain and Croatia is more significant for the lower number of PV modules and for the larger number of PV modules, there is a small difference. The difference between Germany and Croatia is very significant for the low and high number of PV modules.
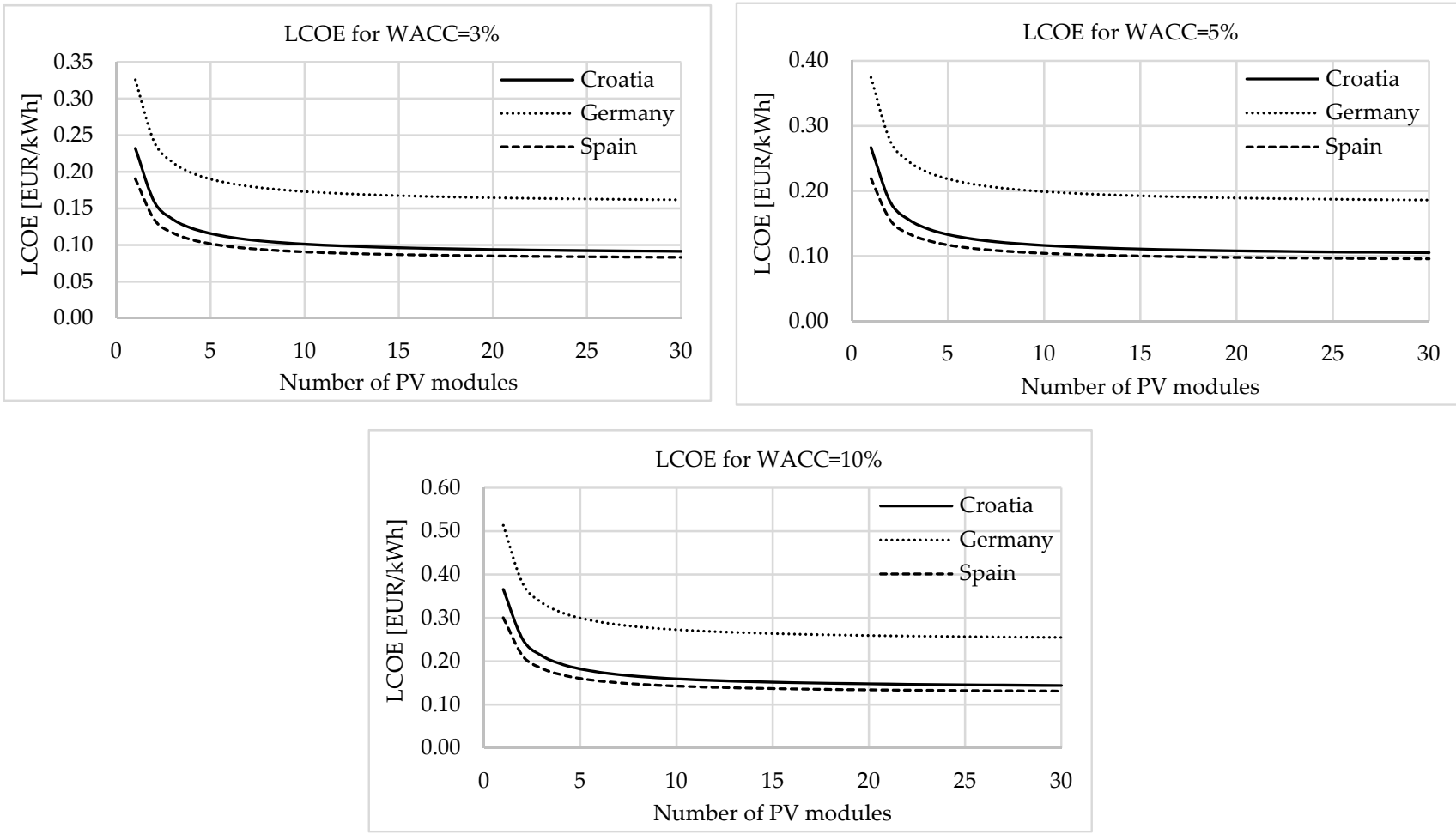

Figure 16. Comparison of LCOE for WACC of 3, 5 and 10\% between Croatia, Germany and Spain. 
Author Contributions: Investigation, Z.Š. and G.K.; Methodology, D.T. and I.C. All authors have read and agreed to the published version of the manuscript.

Funding: This work was funded by the Faculty of Electrical Engineering, Computer Science and Information Technology Osijek under the project "Distribuirana proizvodnja energije u naprednim elektroenergetskim mrežama (FERIT ZP)" and by the Croatian Science Foundation under the pro-ject "Prosumer-rich distribution power network" (project number: UIP-2020-02-5796).

Institutional Review Board Statement: Not applicable.

Informed Consent Statement: Not applicable.

Data Availability Statement: Not applicable.

Conflicts of Interest: The authors declare no conflict of interest.

\section{References}

1. Endo, E.; Kurokawa, K. Sizing procedure for photovoltaic systems. In Proceedings of the 1994 IEEE 1st World Conference on Photovoltaic Energy Conversion-WCPEC (A Joint Conference of PVSC, PVSEC and PSEC), Waikoloa, HI, USA, 5-9 December 1994; pp. 1196-1199. [CrossRef]

2. Kaye, R. A new approach to optimal sizing of components in stand-alone photovoltaic power systems. In Proceedings of the 1994 IEEE 1st World Conference on Photovoltaic Energy Conversion-WCPEC (A Joint Conference of PVSC, PVSEC and PSEC), Waikoloa, HI, USA, 5-9 December 1994; pp. 1192-1195. [CrossRef]

3. Masi, J.; Nadeau, C.; Smith, J. Sizing photovoltaic systems components for stand-alone operation. In Proceedings of the 2007 Electrical Insulation Conference and Electrical Manufacturing Expo, Nashville, TN, USA, 22-24 October 2007; pp. $432-436$. [CrossRef]

4. Wagner, T.; Lang, E.; Assink, W.; Dudis, D. Photovoltaic System Optimization for an Austere Location Using TimeSeriesData. In Proceedings of the 2018 IEEE 7th World Conference on Photovoltaic Energy Conversion (WCPEC) (A Joint Conference of 45th IEEE PVSC, 28th PVSEC \& 34th EU PVSEC), Waikoloa, HI, USA, 10-15 June 2018; pp. 1239-1243.

5. Vigneswaran, A.; Majid, S.; Rahman, H.A.; Hassan, M.Y.; Hamzah, M.K. Cost comparison between Amorphous Silicon and cadmium telluride for stand-alone photovoltaic system in Malaysia. In Proceedings of the 2008 IEEE 2nd International Power and Energy Conference, Johor Bahru, Malaysia, 1-3 December 2008; pp. 468-472. [CrossRef]

6. Afrouzi, H.N.; Mashak, S.V.; Dastgheib, A.M.; Tavalaei, J. Economic Sizing of Solar Array for a Photovoltaic Building in Malaysia with Matlab. In Proceedings of the 2011 First International Conference on Informatics and Computational Intelligence, Bandung, Indonesia, 12-14 December 2011; pp. 306-311.

7. Thebault, M.; Gaillard, L. Optimization of the integration of photovoltaic systems on buildings for self-consumption-Case study in France. City Environ. Interact. 2021, 10, 100057. [CrossRef]

8. Marańda, W.; Piotrowicz, M. Sizing of photovoltaic array for low feed-in tariffs. In Proceedings of the 2014 Proceedings of the 21st International Conference Mixed Design of Integrated Circuits and Systems (MIXDES), Lublin, Poland, 19-21 June 2014; pp. 405-408. [CrossRef]

9. Nikhil, P.G.; Subhakar, D. Sizing and Parametric Analysis of a Stand-Alone Photovoltaic Power Plant. IEEE J. Photovolt. 2013, 3, 776-784. [CrossRef]

10. Nikhil, P.G.; Subhakar, D. Approaches for Developing a Regression Model for Sizing a Stand-Alone Photovoltaic System. IEEE J. Photovolt. 2014, 5, 250-257. [CrossRef]

11. Nikhil, P.G.; Subhakar, D.; Singh, S.J. Solar photovoltaic (PV) system sizing: Considerations from name plate specifications. In Proceedings of the 2015 International Conference on Control Communication \& Computing India (ICCC), Trivandrum, India, 19-21 November 2015; pp. 271-274. [CrossRef]

12. Engel, E. Sizing of a Photovoltaic System with Battery on the Basis of the Multi-Agent Adaptive Fuzzy Neuronet. In Proceedings of the 2016 International Conference on Engineering and Telecommunication (EnT), Moscow, Russia, 29-30 November 2016; pp. 49-54. [CrossRef]

13. Chen, S.-G. Optimal sizing stand-alone PV systems in terms of extreme value theory. In Proceedings of the TENCON 2009-2009 IEEE Region 10 Conference, Singapore, 23-26 January 2009; pp. 1-6. [CrossRef]

14. Makhalfih, A.; Braik, A.; Barakat, D.; Kahtib, T. PVOpt: A user-friendly software for optimally sizing standalone photovoltaic power systems for Palestine. In Proceedings of the 2017 14th International Conference on Smart Cities: Improving Quality of Life Using ICT \& IoT (HONET-ICT), Irbid/Amman, Jordan, 9 November 2017; pp. 40-44.

15. Da Silva, J.R.C.; Pacheco, G.M. Open Source Software Development in Matlab for Sizing Photovoltaic Systems. In Proceedings of the 2018 13th IEEE International Conference on Industry Applications (INDUSCON), Sao Paulo, Brazil, 12-14 November 2018; pp. 256-262.

16. Rosselan, M.Z.; Sulaiman, S.I. Dolphin echolocation algorithm for optimal sizing of grid-connected photovoltaic system. In Proceedings of the 2018 IEEE International Conference on Applied System Invention (ICASI), Chiba, Japan, 13-17 April 2018; pp. 1252-1255. 
17. Sivakumar, L.; Sivakumar, S.; Prabha, A.; Rajapandiyan, A. Implementation of Particle Swarm Optimization for Maximum Power Absorption From Photovoltaic System Using Energy Extraction Circuit. In Proceedings of the 2019 IEEE International Conference on Intelligent Techniques in Control, Optimization and Signal Processing (INCOS), Tamilnadu, India, 11-13 April 2019; pp. 5-8. [CrossRef]

18. De Souza, J.S.; Molina, Y.P.; De Araujo, C.S.; De Farias, W.P.; De Araujo, I.S. Modified Particle Swarm Optimization Algorithm for Sizing Photovoltaic System. IEEE Lat. Am. Trans. 2017, 15, 283-289. [CrossRef]

19. Moreira, H.S.; Silva, J.L.D.S.; Prym, G.C.S.; Sako, E.Y.; Dos Reis, M.V.G.; Villalva, M.G. Comparison of Swarm Optimization Methods for MPPT in Partially Shaded Photovoltaic Systems. In Proceedings of the 2019 International Conference on Smart Energy Systems and Technologies (SEST), Porto, Portugal, 9-11 September 2019; pp. 1-6. [CrossRef]

20. Khan, A.; Javaid, N. Jaya Learning-Based Optimization for Optimal Sizing of Stand-Alone Photovoltaic, Wind Turbine, and Battery Systems. Engineering 2020, 6, 812-826. [CrossRef]

21. Huang, P.; Sun, Y.; Lovati, M.; Zhang, X. Solar-photovoltaic-power-sharing-based design optimization of distributed energy storage systems for performance improvements. Energy 2021, 222, 119931. [CrossRef]

22. Breen, M.; Upton, J.; Murphy, M. Photovoltaic systems on dairy farms: Financial and renewable multi-objective optimization (FARMOO) analysis. Appl. Energy 2020, 278, 115534. [CrossRef]

23. Topić, D.; Knežević, G.; Fekete, K. The mathematical model for finding an optimal PV system configuration for the given installation area providing a maximal lifetime profit. Sol. Energy 2017, 144, 750-757. [CrossRef]

24. Muthuvel, P.; Daniel, S.A.; Paul, S.K. Sizing of PV array in a DC nano-grid for isolated households after alteration in time of consumption. Eng. Sci. Technol. Int. J. 2017, 20, 1632-1641. [CrossRef]

25. Nayak, P.K.; Mahesh, S.; Snaith, H.J.; Cahen, D. Photovoltaic solar cell technologies: Analysing the state of the art. Nat. Rev. Mater. 2019, 4, 269-285. [CrossRef]

26. Gharahcheshmeh, M.H.; Tavakoli, M.M.; Gleason, E.F.; Robinson, M.T.; Kong, J.; Gleason, K.K. Tuning, optimization, and perovskite solar cell device integration of ultrathin poly(3,4-ethylene dioxythiophene) films via a single-step all-dry process. Sci. Adv. 2019, 5, eaay0414. [CrossRef] [PubMed]

27. PVGIS. Photovoltaic Geographical Information System. EU Science Hub_European Commission. 2012. Available online: https: / / ec.europa.eu/jrc/en/pvgis (accessed on 28 April 2021).

28. Topić, D.; Knežević, G.; Kosić, D.; Perko, J. Simplified Model for Optimal Sizing of the Off-Grid PV System Regarding Value of Loss of Load Probability. Teh. Vjesn. Tech. Gaz. 2018, 25, 420-426. [CrossRef]

29. Ministry of Economy and Sustainable Development. Law of the Renewable Energy Sources and the Highly Efficient Cogeneration. 2018. Available online: https://www.zakon.hr/z/827/Zakon-o-obnovljivim-izvorima-energije-i-visokoučinkovitoj-kogeneraciji (accessed on 24 April 2021).

30. Narbel, P.A.; Hansen, J.P.; Lien, J.R. Energy Technologies and Economics. Energy Technol. Econ. 2014. [CrossRef]

31. Patrono, G.; Vergura, S.; Pavan, A.M. LCOE for Zero-Energy Greenhouse. In Proceedings of the 2015 International Conference on Renewable Energy Research and Applications (ICRERA), Palermo, Italy, 22-25 November 2015; pp. 1291-1295. [CrossRef]

32. FERIT. FERIT Reslab. Available online: https:/ / reslab.ferit.hr/ (accessed on 28 April 2021).

33. Eurostat. Electricity Price Statistics. Available online: https://ec.europa.eu/eurostat/statistics-explained/index.php?title= Electricity_price_statistics (accessed on 2 July 2021).

34. Toporek, M.; Campos, I. Assessment of Existing EU-Wide and Member State-Specific Regulatory and Policy Frameworks of RES Prosumers. Prosumers for the Energy Union: Mainstreaming Active Participation of Citizens in the Energy Transition (Deliverable N³.1). 2019. Available online: https://proseu.eu/sites/default/files/Resources/PROSEU_\%20D3.1 RegulatoryFrameworksRES_Prosumers.pdf (accessed on 2 July 2021). 